\title{
Port Integration for Enhancing Competitive Advantage
}

\author{
M. Bina Celine Dorathy
}

\begin{abstract}
With its long coastline and strategic location, India is supposed to be in a dominant position in maritime transportation. But due to poor infrastructure and policy framework, the country extensively depends on other maritime nations such as Singapore and Colombo for transshipment. This increases the cost of exports and imports thereby placing India at a disadvantage in the global market. In response to this alarming situation, the government has taken a major initiative to promote three transshipment ports with world class facilities in the southern part of India. It is expected that these ports would compete with other transshipment ports, particularly with Colombo, and bring the transshipped cargo back to India. This paper makes an attempt to assess the competitive environment that is likely to emerge when all the three ports become operational and suggest a suitable strategy for them to enhance their competitiveness in the new environment.

Biography: M.Bina Celine Dorathy is a doctorate in the area of foreign trade. She is a gold medalist in MBA shipping and logistics. She has been in the field of teaching for almost 20 years. Her areas of interest are International Business and Finance. She is also a corporate trainer. She is actively involved in research guidance. She has published several articles in national and international journals
\end{abstract}

\section{I.INTRODUCTION}

Shipping plays a crucial role in the economic development of maritime nations. India, being a maritime nation is still struggling to be on par with international standards. Inadequate policy initiatives have crippled the country from booming into a maritime hub. Therefore to give a major thrust to this sector, the Maritime Agenda 2020 was launched by the Ministry of shipping. One of its agendum is to create new ports with world class facilities to make India an attractive destination for maritime activities.

India's ports are located either on east or on the west coast. Most of the ports on the west coast are gateway ports, therefore goods are sent directly to destinations. However, the ports on the east coast do not have adequate infrastructure and the country depends on other maritime nations for transshipment. Transshipment refers to shipment of containers to an intermediate destination for loading to other ships bound to other destination. The container transshipment terminal is like a hub where smaller vessels bring cargo from all around and then this cargo is loaded onto larger ships for final destinations or vice versa [1]. Since large ships cannot reach all smaller ports due to their weight, special transshipment deep ports are needed which unfortunately India is short of. As a result, more than $80 \%$ of India's cargo containers are sent to Colombo, Singapore, Port Klang (Malaysia) and Dubai for transshipment, out of this, Colombo alone accounts for around 43\% [2].

Revised Manuscript Received on July 18, 2019.

Dr. M. Bina Celine Dorathy, Associate Professor, AMET Business School ,AMET University, Chennai, Tamil Nadu, India.
Fig.1

Indian Sub-continent Transshipment

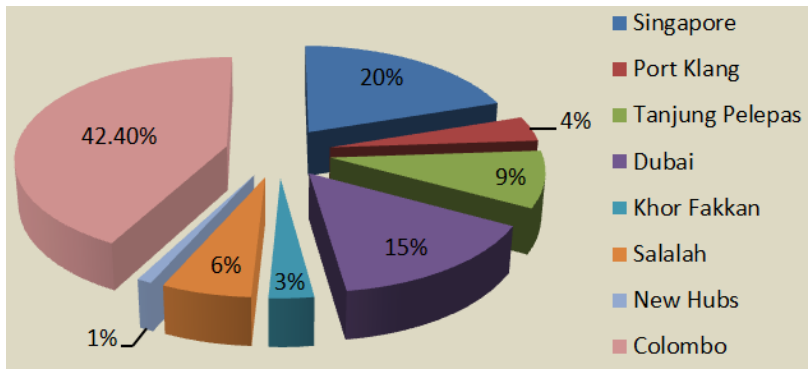

Source : www.vizhinjamport.in/download/VizhinjamInternational-Seaport-PIM.pdf

The country annually pays Rs. 1500 crores towards transshipment [3].This results in additional handling charges that increases the cost of exports and imports, thereby eroding the competitiveness of the country. All this could be avoided if a major thrust is given to India's port sector in line with the maritime agenda. The government therefore has taken the initiative to promote three new ports with transshipment facilities in the southern part of the country. This move is expected to transform India into a container transshipment hub for the Asia-Africa, Asia-US/ Europe container traffic trade.

\section{THE ASSESSMENT OF COMPETITION}

Transshipment is basically a cost game, which means these ports may have to work out new strategies to offer their services at a price lower than that of their competitors to attract business. While doing so the Vallarpadam experience must be borne in mind. These ports though they have a common agenda to compete with Colombo, they would also simultaneously be vying with each other for business because of their location. This homogeneous competition would undermine their ability to have a cost edge over other countries. At this juncture an understanding of the different types of port competition would throw light on the competitive environment that is likely to emerge for these ports.

Port competition can be categorized into three main types

1. Inter-port competition

2. Intra-port competition

3. Inter-port competition at the port authority level.

Inter-port competition [4] can be defined as the competition between different ports. This happens when 
ports are sharing common hinterland. This can further be classified into three subcategories. The first is competition between the whole port range and coastlines. The second type is the competition between ports in different countries. The third type is competition at the national level where competition takes place among different ports within the same country as ports are serving the same overlapped hinterlands. competition within the port which is mainly linked to terminal operators, ownerships and port administration. This can assume two forms. The first is a direct competition between terminals operating in the same port. The second form is one where operators using the same terminal compete with each other. The level of competition in this case directly determines the flexibility of terminal operators. A special case occurs when the port authority acts as a competitor, i.e. when a port authority has shares in port undertakings or terminal operators.

Inter -port competition at port authority[6] level exists between port authorities at a national, local, regional or international level. It can be clearly identified when the rival ports share the same market and handle the same cargo type.

A careful assessment indicates that these three ports of India would be facing an environment characterised by the following features

\section{Interport competition within the country:}

The three ports are located in close proximity to each other. Vizhinjam is $225 \mathrm{kms}$ from Vallarpadam and Enayam is just $36 \mathrm{kms}$ from vizhinjam. As container transshipment hubs they will be competing in the same market for the same type of cargo.

2. Competition between national and regional port authorities: done both by central as well as the state governments. In this case, Vallarpadam and Enayam are major ports coming under the union government and are located within the jurisdiction of Kerala and Tamilnadu. On the other hand Vizhinjam port is owned by the state government of Kerala. This is likely to create conflicting interests among the port authorities. Already Kerala government has expressed its displeasure over the union government's decision to construct Enayam port at such close range.

\section{Intra-port competition:}

The development of transshipment terminals have been entrusted to private bodies both in the case of Vallarpadam and Vizhinjam. Since the union as well as the state governments have regulations not to set up competing facilities detrimental to the interests of private investment, competition between terminal operators may not be present in the initial years, but interestingly the port authority itself acts as a competitor here. In the case of Vallarpadam port the container terminal operator DP World has to share $33.30 \%$ of its revenue with Cochin port trust [7]. With the port operating at less than half of its installed capacity the terminal developer was virtually left with nothing. This was one of the reasons for the DP World not being successful at Vallarpadam.
Intra -port competition [5] can be described as the

India has a federal structure where port administration is

\section{Interport competition from other countries:}

Heavy competition is already prevailing in the region. The market is dominated by Singapore, Malaysia and Colombo offering high quality service in maritime transport that is hard to match. In addition, the port expansion activities undertaken by Colombo would further intensify competition [8]. Therefore it is going to be a herculean task for Indian ports to penetrate the market.

\section{PORT INTEGRATION - THE SUGGESTED MODEL \& RESULTS}

Huge capital both private and public has been invested into these ports to create world class facilities. All this may be recovered only by building it into the tariff structure. But they can gradually be brought down if the ship calls are increased. But again high port charges would be a constraint to attract ship calls. The Vallarpadam experience clearly proved this.

Therefore it is high time the country looks for some alternative strategy to deal with this situation. This paper suggests that port integration can be considered as an option to achieve operational efficiency and thereby reduce costs. This may be done based on the Chinese model. China has been steadily promoting port integration over recent years by bringing the country's main ports into the arms of one provincial-level platform as a way to demonstrate the effectiveness of combining port resources. East China's Zhejiang Province took the lead by establishing in 2015 a provincial-level platform - Zhejiang Port Investment Operation Group (ZPIO) - to optimize port assets in the region, including its five major ports, Ningbo Port, Zhoushan Port, Jiaxing Port, Taizhou Port and Wenzhou Port [9]. In the first stage, ZPIO brought together the ports of Ningbo and Zhoushan to establish Ningbo Zhoushan Port $\mathrm{Co}$, that turned out to be the world's busiest port in terms of cargo tonnage, recording 889 million tons in throughput in 2015 alone [10]. With this, Zhejiang's other ports followed suit, and were gradually unified under ZPIO.

The Indian scenario offers a conducive environment for port integration. Integrating these ports under a common body and entrusting it with the management of their assets would help to rationalise the resources and gain competitive edge against other countries. This may also help to resolve conflicting interests between port authorities. For example the vallarpadam port is prone to siltation and requires heavy dredging. This considerably increases the cost of the port. But if the three ports are jointly administered Vallarpadam may be used as a place to provide value added services and not for berthing of ships. The other two ports with natural drafts may be used for this purpose. In this way operational efficiency can be brought in to reduce costs, besides this would also help to avoid the threat of overcapacity.

The long term perspective of India is to become a maritime hub in the region. Therefore besides transshipment services these ports may also have to provide a wide range of maritime services. Integrating them would ensure proper planning and optimum utilisation of facilities created. It is to 
be noted that the ports in Singapore and Colombo, the two major hubs are being administered by a single authority. The Maritime and Port Authority of Singapore (MPA) is responsible for the overall development and growth of port of Singapore [11] while the Sri Lanka Ports Authority (SLPA) develops, operates and maintains ports in Srilanka [12]. Bringing the three ports under a single independent authority would give them the flexibility to operate in a highly competitive environment. But since private capital is also involved in the development of these ports, this exercise requires guidance from government.

\section{CONCLUSION}

In a major effort to establish itself as a transshipment centre, India has created a cluster of ports in an ideal location. The three ports Vallarpadam, Vizhinjam and Enayam are expected to play a dominant role in transforming India into a maritime hub. But this is going to be a big challenge since these ports are likely to face a two pronged attack. One would be interport competition within the country and the other would be interport competition from other countries. Interport competition within the country can be eliminated through appropriate measures and the same can be used as a strategy to compete with other countries. Integrating the three Ports under a common body would strengthen them and could be an effective strategy to combat competition from powerful transshipment hubs such as Colombo and Singapore.

\section{REFERENCES}

1. P.Manoj, 2016, Can India's container transhipment hubs take on Colombo?, retrieved from https://www.livemint.com > Politics >

2. Nidhi Jamwal,2017, Does South India Need Three TransShipment Ports to Compete With Colombo? retrieved from https://thewire.in/economy/south-india-transshipment-ports-e nayam

3. Ibid

4. Mohamed El Kalla, Damir Zec, Alen Jugović 2017, Container ports competition in light of contemporary liner shipping market dynamics, Multidisciplinary Scientific Journal of Maritime Research

5. Ibid

6. Ibid

7. Socio-economic impact of displacement- a study of Vallarpadam container terminal, Kochi, Chapter 4, p. 116 retrieved from shodhganga.inflibnet.ac.in/bitstream/10603/42080/17/17 chapter4.pdf

8. Project No 5 Colombo Port Expansion Project Under Public Private Partnership (PPP) Basis Retrieved from https://india.trade.gov.pl/pl/f/view/fobject id:429171

9. Zhang Hongpei 2017, The port integration period, Global Times, retrieved from www.globaltimes.cn/content/1071407.shtml

10. Ibid

11. Retrieved from Maritime and Port Authority of Singapore website https://www.mpa.gov.sg/web/portal/home/about-mpa

12. Retrieved from Sri Lanka Ports Authority website www.slpa.lk 